\title{
KURIOS
}

(Jurnal Teologi dan Pendidikan Agama Kristen)

Vol. 3, No. 1, Oktober 2015 (1-11)

ISSN 2406-8306 (print)

http://www.sttpb.ac.id/e-journal/index.php/kurios

\section{Mission And Evangelism: African Context}

\author{
Halim Wiryadinata \\ Sekolah Tinggi Teologi Pelita Bangsa Jakarta \\ ketua@sttpb.ac.id
}

\section{Introduction}

This essay is a critical assessment of the shift in message and meaning of mission since the Edinburgh 1910 Conference. The essay will also include a clarification of the Lausanne documents on mission discussed by John Stott. Against the background of this critical assessment, I will suggest what should be the content and expression of the Gospel as it would be presented in an African context as discussed by David Gitari and Byang Kato. But before I discuss the above I will highlight the tension in mission.

Theologians have argued over many years on what is the main priority of mission. Some theologians suggest that the chief purpose of mission is to evangelise; others have argued that it is to show love to our neighbours and others have said to undertake social action.1 It seems that there is an on going debate on mission. On the one hand, evangelicals advocate evangelism alone and on the other hand, there is a movement from evangelism onto evangelism plus social action. Thus we are led to look at the general background on 'mission' and eventually we propose the expression of the Gospel, when we put it in African context.

\section{The Background Of Mission Since Edinburgh 1910 Conference}

Near the beginning of this century, in 1910 more than 1200 representatives of mission gathered in Edinburgh. The conference was under the slogan 'The Evangelisation of the World in this Generation'. ${ }^{2}$ The conference itself emphasised that each generation has responsibility for evangelising and the development of the work of the mission (e.g. publication of the Bible in many languages). They, however, reported that "the primary

\footnotetext{
${ }^{1}$ Bowen, Roger, ...So I Send You (A Study Guide to Mission), (London, SPCK, 1996), pp. 63-64

${ }^{2}$ Harold, Fuller, Mission-Church Dynamics (How to Change Bicultural Tensions into Dynamic Missionary Outreach), (California, William Carey Library, 1980), p. 47
} 
purpose of mission was understood as the evangelisation of the non Christianworld . " ${ }^{3}$ But at the Edinburgh Conference, according to Arthur Johnston, two notable new points appear: firstly there is a tolerance regarding the elements of non-Christian religion and secondly, "compromising of the universal and emphatic witness to theabsohtteness of the Christians faith by a new attitude of charity and tolerance. "4

As a result of this first ecumenical missionary conference in Edinburgh, they formed the International Missionary Council (IMC), where its aim was "to further proclamation to the whole world of the Gospel of Jesus Christ, to the end that all men may believe and be saved." ${ }^{5}$ By 1961, the IMC was incorporated into the World Council of Churches (WCC) and so at the third World Assembly of the WCC in India, the IMC became the Commission on World Mission and Evangelism (CWME). ${ }^{6}$ In 1968 the fourth Assembly of the WCC met at Sweden (Uppsala), where the talk was of 'New Mission'. They said, "whereas turning people to God had been the goal of traditional mission (Christinisation), today the concern was with enabling people to be truly human (humanisation). ${ }^{7}$ As a result, most evangelicals reacted strongly against this change in the understanding of mission. The climax of the evangelicals' anger came when there was a programme to raise funds for oppressed racial groups in Zimbabwe in 1969. This led to Donald McGravan's criticism under the article 'Will Uppsala Betray the Two billion?' in which he expressed fear that the Assembly will not give attention to the people who have not heard the Gospel. ${ }^{8}$

The Lausanne Congress, officially the International Congress on World Evangelisation, met in July 1974. Billy Graham, in the opening address, said that the Congress' hoped state the relationship between evangelism and social action. John Stott, in the plenary session, urged that they should speak of total mission. This meant that mission should include evangelism and social action. ${ }^{9}$ Lausanne, however, at the end of the Congress declares: "...although reconciliation with man is not reconciliation with God, nor is

\footnotetext{
${ }^{3}$ Gnanakan, Ken., Kingdoms Concern (A Theology of Mission Today), (Leicester, IVP, 1989), p. 16

${ }^{4}$ Johnston, Arthur P., 'The Unanswered Prayer of Edinburgh', Christianity Today, (Vol. 19, no. 4, 22 November 1974), p. 10

${ }^{5}$ Chester, Timothy, Awakening to A World of Need, (Leicester, IVP, 1993), p. 61

${ }^{6}$ Ibid.

${ }^{7}$ Ibid., p. 62 1968)

${ }^{8}$ See McGravan, Donald, 'Will Uppsala Betray two Billion?', Church Growth Bulletin, (Vol. 4, no. 5

${ }^{9} 9$ See Timothy Chester, op. cit., p. 72; it seems that John Stott moves his position from denying the social action as part of mission, but at Lausanne he expresses differently. (see Stott, John, 'The Great Commission', in Carl F. Henry and Stanley Mooneyham eds., The official Reference Volumes: One Race, One Gospel, One Task, (vol. 1), (Minneapolis, World Wide Publication, 1967), pp. 50-51
} 
social action evangelism, nor is political liberation salvation, nevertheless we affirm that evangelism and social action and political involvement are both part of our Christian duty" $^{10}$ On the other hand, they affirm that 'evangelism is primary' and they urged the Christian community must make known the Gospel, not only through proclamation, but also through life as the new society and through the pursuit of justice. ${ }^{11}$

Since then, the meaning of mission has altered from the preaching of the Gospel to socio-political involvement and evangelism (holistic mission). As Rene Padilla puts it: "social involvement had finally been granted frill citizenship in evangelical missiology". ${ }^{12}$

\section{Analysis and Result}

\section{The Evangelical Position On Mission}

From what has been said above, it follows that the evangelicals intended to keep mission as "verbally proclaiming the Word and saving individual souls. " ${ }^{13}$ In other words, without preaching the Gospel of Jesus Christ there is no a mission. This is why Evangelicals were very slow to respond to social action and raised three criticisms. Firstly, they said that there is a possibility that the Gospel of Jesus Christ will become the 'Social Gospel', where there is a shift of emphasis from 'preaching the Gospel', by the church and the christianisation of society by socio-political, economic and cultural influences. ${ }^{14}$ Secondly, they said that, "mission has constantly suffered from being confused with charity and relief The motive appealed to has been that of compassion rather than obedience or witness ...Human need is not to be measured in term of income... The rich also needs the Gospel of Jesus Christ." ${ }^{15}$ is Thirdly, they raised at least three questions: is 'Social Action' identical to evangelism in the sense of proclaiming the truth of eternal salvation? Does mission include social and political involvement and if so, how? Where does the salvation take place?

Additionally, Tite Tienou challenges those who hold that the mission of the church includes evangelism and social action with the question: does our social action really contribute to restoring human dignity and wholeness? ${ }^{16}$ He sees the restoration of human

\footnotetext{
${ }^{10}$ Stott, John, Making Christ Known (Historic Mission from the Lausanne Movement 1974-1989), (Michigan, The Paternoster Press, 1996), p. 24

${ }^{11}$ See Timothy Chester, op. cit., p. 81

${ }^{12}$ Padilla, Rene, 'How Evangelical Endorsed Social Responsibility' , Transformation, (Vol. 2, No. 3, 1985), p. 25

${ }^{13}$ Cho, Chongnahm, 'The Mission of the Church Theology and Practice', In Word and Deed (Evangelism and Social Responsibility), ed. Bruce Nicholls, (Michigan, The Paternoster Press, 1985), p. 216

1414 See Cho, Chongnahm, op. cit., p. 216

${ }^{15}$ Webster, Douglas., Yes to Mission, (London, SCM Press, 1966), p. 23

${ }^{16} 16$ Tienou, Tite, 'Response to Dr. Cho', op. cit., p. 238
} 
dignity and wholeness of the person is found in Christ. This he said comes through the communication of the Gospel. ${ }^{17} \mathrm{He}$, therefore, argues that "institutionalised social action means impersonal involvement and this has disastrous results, "18 even though they may use it for the purpose of increasing their power and respectability within society.

On the other hand, Johnston is critical of the position of John Stott, who described social action as the partner of evangelism. Johnston accuses Stott of having 'dethroned evangelism as the only historical aim of mission'. ${ }^{19}$ For Johnston, mission is evangelism alone because if we emphasis too much on social action it inevitably leads to abandonment of evangelism. Paul Rees supports him by citing the way racism can be a hindrance to the Gospel." ${ }^{20}$ Johnston and Paul Rees do not seem to be happy with the Lausanne Covenant which maintains that 'evangelism is primary'. ${ }^{21}$ The Lausanne Congress in section 6 say "it is not enough and it should retained not only its priority and primacy, but also the unique status it held from the 19th century to Berlin. "22 Likewise Peter Wagner criticises Lausanne by saying "not only did the Lausanne program build on what I consider a disproportionate emphasis on social aspects of the Christians mission for a Congress on World Evangelisation, but many influential media reports even exaggerated this, thereby diluting the evangelist components. $^{23}$

\section{The Lausanne Position On Mission}

Rene Padilla and Samuel Escobar, who have been described by John Stott as those 'who set the cat among the pigeons', are very influential men within Lausanne affirmation and emphasis the issue of social action and its relationship to the Gospel. At the heart of Padilla's and Escobar's concern is the fear that the evangelicals and the Congress will give attention to the evangelistic strategy for the sake of numbers and replace the Gospel with the 'Cheap Gospel'. $^{24}$

As Samuel Escobar argues, "the danger of evangelicalism is that it will present a saving work of Christ without the consequent ethical demand, that it will present a Saviour

${ }^{17} 17$ See Ibid., p. 238

${ }^{18} 18$ Ibid., p. 238

1919 See Arthur Johnston, which is cited on Timothy Chester, op. 307

${ }^{20}$ Rees, Paul, The Official Reference Volumes: One race, One Gospel, One Task (vol.2), op. cit., p.

${ }^{21}$ See Stott, John, making Christ Known, op. cit., p. 24

${ }^{22}$ Johnston, which is cited on Timothy Chester, op. cit., p. 83

${ }^{23} 23$ Wagner, Peter, 'Lausanne Twelve Months Later', Christianity Today, (Vol.19, No.20, 4 July 1975), p. 6

${ }^{24}$ See Chester, Timothy, op. cit., p. 73 
who delivers from the bondage of spiritual slavery but not a model of the lift that the Christian should live in the world. A spirituality without the discipleship in the daily social, economy, and political aspects of lift is religiosity and not Christianity. "25

Rene Padilla arguing from a different angle says that the only true evangelism is that which seeks the restoration of all things in Christ. Padilla says that the church has been entered by the world. Firstly, there is 'secular Christianity', which excludes the supernatural and secondly, 'culture Christianity', which arises when "the Christian faith confuses aspects of Christianity with political conservatism and its tendency to treat the Gospel as a product to be marketed as efficiently as possible. " ${ }^{26}$ In other words, Padilla's fear is that the concentration on technology and efficiency to measure numerical success of the church will undermine the integrity of the Gospel." 27

Cho challenges the position of the evangelicals by saying that in Jesus' ministry, He uses both word and deed to minister to people as he announces the kingdom of God, ${ }^{28}$ because faith without works is dead. ${ }^{29}$ He asserts very strongly that we should not assume social action as preparation for evangelism, nor a manifestation or by product of evangelism. Both evangelism and social action are a Christian's duty, because every Christian is a witness and a servant. ${ }^{30}$ John Stott says very clearly that Gospel preaching and compassionate service, for Jesus, go hand in hand. ${ }^{31}$ This is because His Works express His Words and His Words express His Works. ${ }^{32}$

\section{An Evalution Of Lausanne And Evangelical On Mission}

From what has been said above, one has to ask regarding evangelism and social action which comes first? This leads the conservatives and 'the radical discipleship ${ }^{33}$ advocate having an on going debate. ${ }^{34}$ Two options, they offer are, firstly, that social action is distinct from, yet equal to evangelism. Secondly, that social action is part of/or, is partner of/or, is included in/or, is a consequence of/or, and proceeds from

${ }^{25}$ Escobar, Samuel., cited on Harold Fuller, op. cit., p. 84

${ }^{26}$ Padilla, Rene, which is cited on Timothy Chester, p. 74

2727 Ibid., p. 74

${ }^{28}$ See Luke 8:1, Acts 10: 38

${ }^{29} 29$ Cho, Chongnahm, op. cit., p. 224

3030 Ibid., p. 228

3131 See Matthew 9: 35-36; Matthew 14:14

$32{ }^{32}$ See Stott, John, Authentic Christianity,op. cit., p. 343 and Sider Ronald, Evangelism and Social Action, op. cit., pp. 144-146

33 Radical discipleship means those who hold mission include evangelism and social action.

${ }^{34}$ See Adeyemo, Tokunboh, 'A Critical Evaluation of Contemporary Perspective', In Word and Deed (Evangelism and Social Action), (Michigan, Paternoster Press, 1985), p. 47 
evangelism. Adeyemo says that social action is apart of evangelism, but he prefers to say that social action is implied in evangelism. ${ }^{35}$ David Gitari seems to support this and says that he is sure that social action is a part of mission.

He says "I have no doubt that the Good News of the Kingdom includes feeding the hungry. " ${ }^{36}$ David Bosch, however, argues against Stott'sposition by saying, "I would not call evangelism and social action separate components or parts of mission, but dimensions of the one, indivisible mission of the church. " ${ }^{37}$ This poses some questions: Does the statement imply that two the are as one component? How would you define evangelism and social action? He, however, seems to contradict himself and identify himself with Stott by saying, "the Iwo are not the same, but neither can they be separated. "38 Stott seems to be correct when he asserts that evangelism and social action are different components and they are inseparable.

He insists though that there is no one relationship in which they join, they are at least equally valid relationships, such as social action as a consequence of, a bridge to, and to accompany evangelism. ${ }^{39}$ He says strongly that evangelism is not social action, nor social action is evangelism. Yet, each involves the other. ${ }^{40}$ Does he mean that social action has implications for evangelism as Adeyemo suggests? How can it be that when you give food to the hungry it has evangelistic implication, without preaching the Gospel? The writer assumes that he or Lausanne needs further clarification on this.

The arguments of Rene Padilla and Samuel Escobar have challenged evangelicals. It is, perhaps, quite true that Western Evangelicals tend to see 'Church Growth', as being independent of social action. As D. J. Mckay says evangelicals have become dismissed in this century as socially irrelevant, because they put emphasis on souls' and do not get involve in social action. ${ }^{41}$ This is why Donald McGravan has been criticised by Lesslie Newbigin, because McGravan seems to hold to the concept of the relation of numerical church growth to the message of the Kingdom. ${ }^{42}$ Newbigin argues that the New Testament does not have any interest in numerical growth, but the mission of the church depends upon

\footnotetext{
${ }^{35}$ Ibid., p. 57

${ }^{36}$ Gitari, David., op. cit., p. 218

${ }^{37}$ Bosch, David., 'In Search of a New Evangelical Understanding', In Word and Deed, op. cit., p. 81

${ }^{38}$ Ibid., p. 82

${ }^{39}$ Stott, John., op. cit. p. 181

${ }^{40}$ Stott, John., op. cit., p. 182

${ }^{41}$ See McKay, D. J, 'Salt in Society: A Kingdom Perspective', Evangel, (vol. 3, no. 3, Autumn 1988), p.

${ }^{42}$ See Newbigin, Lesslie, The Open Secret, (Grand Rapids, William B Eerdmans, 1978), pp. 139- 
the active work of the Holy Spirit, who leads people to the $\mathrm{ft}^{-1} 1 \mathrm{th}^{43}$ Padilla argues that church statistics can be deceptive and the future of the church does not depend on our ability to persuade people to give intellectual assent to a truncated Gospel, but our faithfulness to the full Gospel of Jesus Christ and God's faithfulness to his Word. ${ }^{44}$ So then, there are those who hold that mission is evangelism alone. If so, evangelism must be followed up by in depth teaching and discipling otherwise the work will not prosper.

Evangelicals, however, argue that the Gospel is 'Good News' in that we are forgiven. ${ }^{45}$ On the other hand, Lausanne defines the Gospel is "a 'Good News' of liberation, of restoration, of wholeness and of salvation that is personal, social, global and cosmic." ${ }^{46}$ WCC similarly says "the Gospel of Jesus Christ speaks on behalf of those who have no voice in confronting social and economic injustice, for these affront the love and justice of God. ${ }^{47}$ This makes social action not only part of mission but part of the Gospel. However, evangelicals maintain that the Gospel itself is the proclamation of the person and work of the Lord Jesus Christ, who brought the kingdom of God to this world. While holding the right theology, though they must apply it to social issues as the salt and the light of this world. ${ }^{48}$

The writer, however, believes also that mission involves evangelism and social action. ${ }^{49}$ This is because the Gospel is a message and it must be made known as such ${ }^{50}$ and, on the other hand, the Gospel has the root (the essence) and the fruit (the result). The failure to see the essence and the result, will lead us to 'salvation by works, not by faith'. The essence is preaching the Gospel and the purpose of the fruit is to conform the world to the image of God's Son (Romans 8: 29) in the process of responding to the social evils of the world around us.

The question, however, for us is: how far can we go for social action? The danger of social action is, those people we help come to depend on us, and then, we do not liberate them but dehumanise them. We, however, must work with them in seeking ways and means that leads to self-sufficiency. The author agrees with David Gitari when he says, "the Good News to the hungry must not stop at giving bread which perishes. Evangelism is the

\footnotetext{
${ }^{43}$ Ibid., pp. 145-147: Newbigin uses the argument of Roland Allen, Missionary Methods, (London, World Dominion, 1960), p. 49

${ }^{44}$ Padilla, Rene, which is cited on Fuller Harold, op. cit., p. 84

${ }^{45}$ See Lucas, Dick, 'What is the Gospel?', Christian Arena, (vol. 37, no. 1, 1984), p. 13

${ }^{46}$ Chester, Timothy, op. cit., p. 81

${ }^{47}$ Kolini, Enmianuel, 'A Jubilee Call: A Letter to the World Council of Churches by Evangelical Participants at Harare', Anvil, (Vol. 16, no.1, 1999), p. 16

${ }^{48}$ See McKay, op. cit., p. 16

${ }^{49}$ The illustration can be drawn as 'two blades of a pair of scissors'

${ }^{50}$ See Wetmore, Hugh, 'The Gospel', Evangelical Review Of Theology, (vol. 14, 1990), p. 230
} 
proclamation of the Good News of Jesus Christ so the people understand the message, receive him as the bread of life and incorporated into the Eucharistic lift of the church. " 51

\section{The Meaning Of The Gospel In The Context Of Mission in Africa}

David Gitari remarks that if we want the Gospel to have a deep impact on African people, we must contextualise it in the cultural situation of the Africans. ${ }^{52}$ Byang Kato points out the relevance of Christianity to Africans today. He says that when he was in Malawi. ${ }^{53}$ The reaction of Malawi people was that Christianity is a white man's religion and they declare 'ancestor worship' as their own religion. ${ }^{54}$ Don Jacobs sees the 'incarnation theology' as the pattern for contextualisation in Africa. He says that, "the incarnation principle, therefore, points the way to effective evangelism and strengthening of the church in Africa." ${ }^{55} \mathrm{He}$ argues that the Gospel, according to African people, cannot be effective unless and until it is formulated to function in concrete or specific situation. ${ }^{56} \mathrm{It}$, however, can be so as long as it is Biblical. This is because if it loses the Biblical meaning, the Bible is being interpreted from the praxis perspective.

For some Africans, the Bible seems to be a reflection of their cultural life, because the culture is the vehicle of the message. ${ }^{57}$ The effect of this is ${ }^{58}$, the tendency to absolutise culture and minimise the cultural changes which conversion ought to imply and that people who accept the Gospel ought to retain their traditional culture." ${ }^{59}$ Newbigin argues that even though God accepts culture, but God judges human culture. ${ }^{60} \mathrm{He}$ says, "the Gospel, therefore, is to be addressed to the whole human community, since the real human of its people is bound up inextricably with the language and culture of the whole. " ${ }^{61}$ In this way they can hear the Good News from within their own cultural context

\footnotetext{
${ }^{51}$ Gitari, David, op. cit., p. 219

${ }^{52}$ See Gitari, David., op. cit., p. 215; more detail in the next section, p. 7

${ }^{53}$ See Kato, Byang., 'Christianity as an African Religion', Evangelical Review of Theology, (vol. , no. 7, 1980), p. 31

${ }^{54}$ Ibid., p. 32; another examples see Kings, Graham., 'Facing Mount Kenya: Reflection on the Bible and African Traditional Religion', Anvil, (vol. 4, no. 3, 1987), pp. 127-143

55 Jacobs, Don., cited on David Gitari, op. cit., p. 216

${ }^{56}$ Bediako, Kwame., 'Jesus in African Culture', Evangelical Review of Theology, (Vol. 17, no. 1, January 1993), p. 55

${ }^{57}$ It will lead to Liberation Theology, where they emphasis on critical reflection on praxis. See Gustavo Gutierrez, A Theology of Liberation: History, Politics, and Salvation, (New York, Orbis, 1973), p. 11

${ }^{58}$ See Meeking, Basil and John Stott, The Evangelical Roman Catholic Dialogue on Mission 19771984, (Exeter: Paternoster Press, 1986), pp. 74-75

${ }^{59}$ Vandi, Sheku, 'Culture and Tradition', Ph.D. thesis, p. 8. See also, Newbigin, Lesslie, The Gospel in the Pluralist Society, (London, SPCK, 1989), p. 184

${ }^{60}$ Newbigin, Lesslie, op. cit., p. 195

${ }^{61}$ Newbigin, Lesslie, The Open Secret, (London, SPCK, 1995), p. 141
} 
and express the Gospel in their own thought forms and philosophy and will be able to tackle their problems such as polygamy, family structure and the spirit world. However, the question arises how does the Good News relate to their situation in Africa, where they are struggling against poverty, ignorance and disease?

Lesslie Newbigin remarks that successful evangelistic campaigns and mass conversion reported have often been marked by flagrant evil such as racism, militant and blind support for oppressive economic and political systems. ${ }^{62}$ This is where African people expect the Gospel to bring wholeness and have an interest in the body and society's pains. ${ }^{63}$ Rene Padilla says that the role of culture in African understanding of the Gospel and of mission has been a theme parallel to that of social action. ${ }^{64}$ Bediako Kwame considers the Gospel as the liberator for Gentiles from the regulations of the Jewish law, has the implication for African people as the liberator of their lives including physical and spiritual dimensions. ${ }^{65}$ This is so, because in the African world they require a view of Christ, who meets their needs. Newbigin asks how can we defend a form of evangelism has nothing to say about the big issues of public righteousness and talks of questions of personal and domestic behaviour? Can there any preaching of the 'text' of the Gospel except in an explicit relation to the 'context' of the contemporary world? ${ }^{66}$

Newbigin outlines the interaction between the Gospel and culture in the communication of the Gospel. ${ }^{67}$ Within the receptor community there is a complex evolution determined by three factors, namely the traditional culture, the Christianity of the missionary and the witness of the Bible. ${ }^{68}$ Out of these three things, however, the culture cannot be absolutised over against the Gospel. As Roy Musasiwa observes "the African Traditional Religion (ATR) is the ground of motive of African culture, so if the syncretism is to be eliminated, the Gospel of Christ must be substitute ground motive, for the same culture. "69 The basic premise of Newbigin and Roy Musasiwa is that the Gospel is supracultural, yet it has to exist within any culture. If they are right, then we can start with the universality of the person of Jesus Christ rather than from his particular as a Jew, because

\footnotetext{
${ }^{62}$ Ibid., pp. 134-135

${ }^{63}$ See Cheesman, Graham., Mission Today, (Belfast, Qua Iboe Fellowship, 1989), p. 107

${ }^{64}$ See Padilla, Rene, which is cited on Timothy Chester, p. 92

${ }^{65}$ See Bediako, Kwame, 'Jesus in African Context', Evangelical Review of Theology; (vol. 17, no. 1, January 1993), p. 55

${ }^{66}$ Newbigin, Open Secret, p. 150

${ }^{67}$ Ibid., pp. 157-180

${ }^{68}$ See ibid., p. 168

${ }^{69}$ Musasiwa, Roy, 'The Finality of Jesus in Afr ica', Evangelical Review of Theology, (vol. 17, no. 1, January 1993), p. 68
} 
Jesus is not only a Saviour for the Jews, but for all those who believe in him. ${ }^{70}$ James Buswell insists that Christian Ethnotheology "must be done from inside the system, rendering the supracultural Christian absolutes not only in the linguistic idiom, but also within the particular forms that 'system' takes within the system: concept of priority, sequence, time, and styles of emphasis and expression. "71 The writer, however, assumes that 'Ethnotheology' can be useful as long as it does not lose the meaning of the Scripture. This is so, the truth is not lost and the relative truth is maintained. It is important, however, when thinking of African theology, to remember that it will act on an African agenda.

Kato insists that "the Gospel can be expressed in a truly African context by allowing it to judge the African culture and never allow the culture to take precedence over


theological concepts in terms of the African situation. This is 'scratching where it itches'. It is tackling characteristically African problems related to polygamy, family structure and the spirit world and presenting Biblical answers to these problems. On the other hand, we need to uphold social action, but not at the expense of the message of personal salvation. True converts to Christ become Christians who revolutionise society for good.

\section{Conclusion}

We have seen the on going debate on mission between the evangelical's position, which is evangelism alone, on the one hand, and the Lausanne's position, which is evangelism plus social action, on the other hand. We, however, come to the conclusion that mission is evangelism plus social action, because we are the salt and the light in our society. I propose, therefore, that because evangelism and social action go hand in hand, that the content and the expression of the Gospel in African context is evangelism, permitting indigenous expression of faith and the content of the Gospel (as long as it does not change the meaning of it) and social action for changing society for good.

$707^{\circ}$ Newbigin, Bediako and Musasiwa say that we need to start from who He is (see Open Secret p. 180; Jesus in African Context p. 60-61 and The Finality of Jesus in Africa p. 69).

7171 Buswell, James, 'Contextualisation: Theory, Tradition and Method', Theology and Mission: Papers given at Trinity Consultation, ed. David J. Hesselgrave, (Grand Rapids, Baker Book House, 1978), p. 98

7272 Kato, Byang and John Mbiti, 'Africa', Contextuolisation, eds. Hesselgrave and Edward Rammen, (Michigan, Baker House, 1989), p. 111 


\section{References}

Adeyemo, Tokunboh, 'A Critical Evaluation of Contemporary Perspective', In Word and Deed (Evangelism and Social Action), Michigan, Paternoster Press, 1985

Bediako, Kwame, 'Jesus in African Context', Evangelical Review of Theology, vol. 17, no. 1, January 1993

Bosch, David., 'In Search of a New Evangelical Understanding', In Word and Deed, (Evangelism and Social Action), Michigan, Paternoster Press, 1985

Bowen, Roger, ....So I Send You (A Study Guide to Mission, London, SPCK, 1996 Buswell, James, 'Contextualisation: Theory, Tradition and Method', Theology and Mission:

Papers given at Trinity Consultation, ed. David J. Hesselgrave, Grand Rapids, Baker Book House, 1978

Hesselgrave, David J. and Edward Rommen, Con textualisation, Michigan, Baker House Book, 1989

Cheesman, Graham., Mission Today, Belfast, Qua Iboe Fellowship, 1989

Chester, Timothy, Awakening to A World of Need, Leicester, IVP, 1993

Cho, Chongnahm, 'The Mission of the Church Theology and Practice', In Word and Deed (Evangelism and Social Responsibility), ed. Bruce Nicholls, Michigan, The Paternoster Press, 1985

Gnanakan, Ken., Kingdoms Concern (A Theology of Mission Today), Leicester, IVP, 1989

Graham., 'Facing Mount Kenya: Reflection on the Bible and African Traditional Religion', Anvil, vol. 4, no. 3, 1987

Harold, Fuller, Mission-Church Dynamics (How to Change Bicultural Tensions into Dynamic Missionary Outreach), California, William Carey Library, 1980

13. Johnston, Arthur P., 'The Unanswered Prayer ofEdinburgh',

Christianity Today, (Vol. 19, no. 4, 22 November 1974

Kato, Byang., 'Christianity as an African Religion', Evangelical Review of Theology, vol. , no. 7, 1980

Kolini, Emmanuel, 'A Jubilee Call: A Letter to the World Council of Churches by Evangelical Participants at Harare', Anvil, Vol. 16, no.1, 1999

Lucas, Dick, 'What is the Gospel?', Christian Arena, vol. 37, no. 1, 1984

McKay, D. J, 'Salt in Society: A Kingdom Perspective', Evangel, vol. 3, no. 3, 1988

Meeking, Basil and John Stott, The Evangelical Roman Catholic Dialogue on Mission 1977-1984, Exeter: Paternoster Press, 1986

Musasiwa, Roy, 'The Finality of Jesus in Africa', Evangelical Review of Theology, vol. 17, no. 1, January 1993

Newbigin, Lesslie, The Open Secret, London, SPCK, 1995

Newbigin, Lesslie, The Gospel in the Pluralist Society, London, SPCK, 1989

Padilla, Rene, 'How Evangelical Endorsed Social Responsibility', Transformation, Vol. 2, No. 3, 1985

Rees, Paul, The Official Reference Volumes: One race, One Gospel, One Task (vol.2), Minneapolis, World Wide Publication, 1967

Roland Allen, Missionary Methods, London, World Dominion, 1960

Stott, John, Making Christ Known (Historic Mission from the Lausanne Movement 1974 1989), Michigan, The Paternoster Press, 1996

Vandi, Sheku, 'Culture and Tradition', Ph.D. thesis

Wagner, Peter, 'Lausanne Twelve Months Later', Christianity Today, Vol.19, No.20, 4 July 1975

Webster, Douglas., Yes to Mission, London, SCM Press, 1966

Wetmore, Hugh, 'The Gospel', Evangelical Review Of Theology, vol. 14, 1990 